\title{
Two types of datives in Spanish: Caused possession vs. possessor raising
}

\author{
Héctor Fernández-Alcalde \\ Universidad Autónoma de Madrid \\ h.f.alcalde@gmail.com
}

\begin{abstract}
This paper focuses on the notion of "caused possession" as the key factor responsible for a number of properties that Spanish dative structures show when inspected closely. Among other phenomena, the relationship between dative and prepositional structures is explored and some striking contrasts arising in passive and nominal environments are accounted for. The Spanish dative clitic is analysed as the locus of many of these structural and semantic properties and a unified explanation is offered for Spanish dative assignments in double object-like constructions.
\end{abstract}

Keywords: datives; possession; argument structure; clitic doubling; prepositions

\section{Introduction: Dative case and Spanish second objects}

This paper revisits Fernández-Alcalde's (2013) approach to Spanish dative objects and provides further evidence that the key notions which determine their syntax are affectedness and transfer of possession. Specifically, the article analyses Spanish dative internal arguments, which generally bear the following thematic roles: goal or recipient (1a), beneficiary (1b), location (1c), or possessor (1d). ${ }^{1}$ As shown in the examples, the dative object in (1a) can be optionally doubled by the clitic le (singular)/les (plural), whereas in $(1 \mathrm{~b}-\mathrm{d})$ the doubling is compulsory:

(1) a. Juan (le) entregó un premio a María

Juan CL.DAT delivered a prize María.DAT

'Juan awarded María a prize.'

${ }^{1}$ There are some other types of arguments that also bear dative case in Spanish, such as the experiencer subjects of some psychological predicates and the affected arguments of some unaccusative verbs. This paper will leave aside these cases, but see Masullo (1992); Torrego (1998); Fernández-Soriano (1999a;b); Cuervo (2008; 2010), among others, for evidence that these are high datives occupying a subjectlike position.

1216-8076/\$20.00 @ 2014 Akadémiai Kiadó, Budapest 
b. Juan *(le) preparó un bocadillo a su hija. Juan CL.DAT made a sandwich his daughter.DAT 'Juan made his daughter a sandwich.'

c. Juan *(le) instaló un antivirus al ordenador. Juan CL.DAT installed an antivirus the computer.DAT 'Juan installed an antivirus on the computer.'

d. Juan *(le) rompió el coche a Pedro. Juan CL.DAT broke the car Pedro.DAT 'Juan broke Pedro's car.'

The obligatory presence of clitic doubling in $(1 \mathrm{~b}-\mathrm{d})$ correlates with the possibility of paraphrasing these examples with synonymous prepositional constructions, as shown in (2):

(2) a. Juan preparó un bocadillo para su hija. Juan made a sandwich for his daughter 'Juan made a sandwich for his daughter.'

b. Juan instaló un antivirus en el ordenador. Juan installed an antivirus on the computer 'Juan installed an antivirus on the computer.'

c. Juan rompió el coche de Pedro. Juan broke the car of Pedro 'Juan broke Pedro's car.'

If we put these two observations together, the paradigm of dative second objects as summarised in (3) and (4) arises. Looking at these examples, clitic doubling structures seem to correspond to parallel prepositional constructions, with the particular circumstance that the preposition $a$ heading the ditransitive structure is phonologically identical to the dative marker.

(3) Dative
a. Ditransitive: Juan le entregó un premio a María.
b. Beneficiary: Juan le preparó un bocadillo a su hija.
c. Locative: Juan le instaló un antivirus al ordenador.
d. Possessive: Juan le rompió el coche a Pedro. 
(4) Prepositional

a. Ditransitive: Juan entregó un premio a María.

b. Beneficiary: Juan preparó un bocadillo para su hija.

c. Locative: Juan instaló un antivirus en el ordenador.

d. Possessive: Juan rompió el coche de Pedro.

The analysis presented in the following sections will focus on identifying the argument structure that underlies the apparently similar dative constructions in (3), as well as on establishing the relationship that mediates between them and their prepositional paraphrases. It will ultimately be claimed that, in spite of what the examples in (1) suggest (distinguishing (3a) from the rest in terms of clitic doubling), the structure underlying examples $(3 \mathrm{a}-\mathrm{c})$ is essentially the same: it codifies caused possession, whereas the possessive dative exemplified in (3d) codifies a static possession which undergoes a possessor raising operation. ${ }^{2}$ Following proposals by Demonte (1995), Harley (2003) and Cuervo (2008), among others, I assume (5) as the tentative structure for $(3 \mathrm{a}-\mathrm{c})$, where HAVEP contains a specifier DP, which is assigned dative case by a higher $\mathrm{X}$ head, and a complement DP, which receives accusative case. The structure for (3d) is the one in (6), where the static possessor argument is projected in the specifier of the single DP argument of $\mathrm{V}$ and undergoes further possessor raising attracted by $\mathrm{X}$ - a head we will later identify as inner aspect -, in line with Landau (1999):

(5)

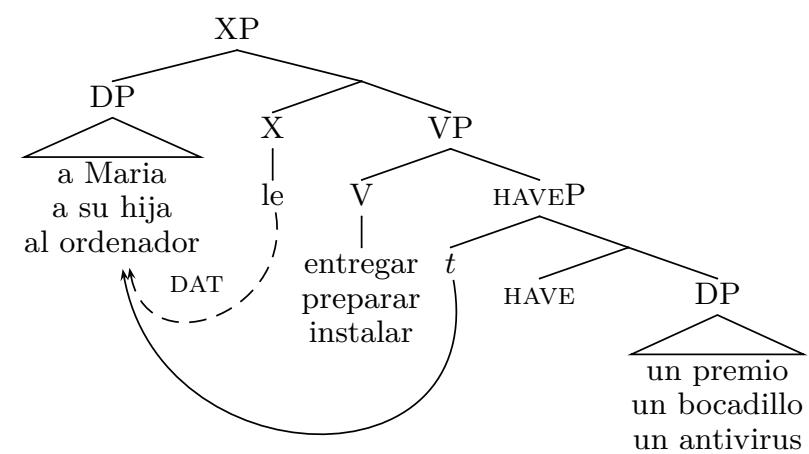

\footnotetext{
${ }^{2}$ For the notion of 'possessive dative', cf. Bally (1926) and Lamiroy \& Delbecque (1998), among many others.
} 
(6)

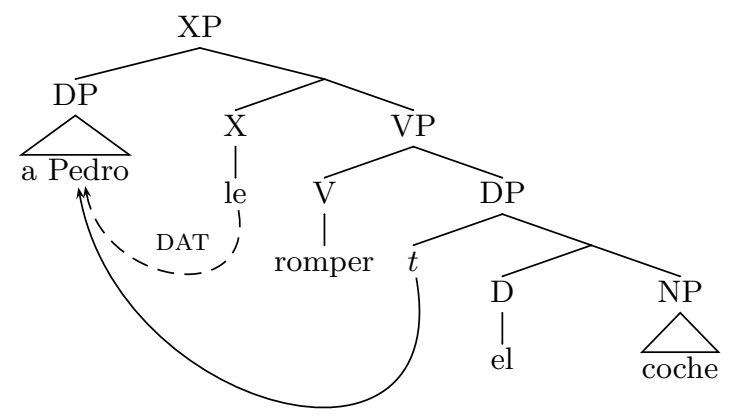

The non-doubling constructions exemplified in (4) are analysed as regular prepositional structures with no dative case involved. The optionality of the clitic in ditransitive structures will then be claimed to be only illusory: the argument relations underlying (1a) can be expressed as a prepositional structure or as a dative structure, where the dative DP is interpreted as an affected argument. Building on Fernández-Alcalde's (2013) analysis, I will introduce new arguments suggesting that affectedness plays a key role in licensing dative arguments. I will argue for the existence of a strong relation between affectedness and the Asp node. Further support from nominalisation and passivisation data will also be supplied in favour of this analysis.

The paper is organized as follows. Section 2 further describes the properties of the constructions in (3) and (4), and it also overviews previous accounts and identifies their limitations. Section 3 develops the analysis advanced in (5) and (6), focusing on caused possession as the key factor distinguishing the two structures. I provide support to the claim that the $\mathrm{X}$ head in (5) and (6) is an instance of Asp, responsible for dative case assignment and the affected interpretation. Section 4 sums up the main results and concludes the paper.

\section{Main properties of Spanish dative structures}

In this section, I will address some of the basic properties of Spanish dative structures, concentrating on the effects of the doubling clitic and on the possibility to nominalise and passivise these constructions. I will also review the main accounts that dative structures have received. 


\subsection{The double object construction in Spanish}

One of the first studies to address the alternation between the cliticdoubled and the non-doubled construction in ditransitives is Demonte (1995). This author analyses these pairs of sentences as equivalent to the English dative alternation, which relates a prepositional and a doubleobject construction. The clitic is no longer regarded as optional, but as the locus of syntactic and semantic properties that reproduce the ones displayed by English double objects, such as c-command asymmetries (Barss \& Lasnik 1986) and animacy/possession constraints (Green 1974; Oehrle 1976; Pinker 1989).

(7) a. *Juan enseñó un retrato de síi misma a cada $i_{i}$ actriz.

Juan showed a portrait of herself to each actress

'Juan showed a portrait of herself to each actress.'

b. Juan le enseñó un retrato de sí $i_{i}$ misma a cada ${ }_{i}$ actriz. Juan CL.DAT showed a portrait of herself to each actress

'Juan showed each actress a portrait of herself.'

(8) a. Juan envió un paquete a Madrid.

John sent a package to Madrid

'John sent a package to Madrid.'

b. ${ }^{*}$ Juan $\mathbf{l e}_{i} \quad$ envió un paquete a Madrid $_{i}$.

Juan CL.DAT sent a package to Madrid

'John sent Madrid a package.'

As (7) shows, only when the clitic is present can the anaphora de si misma 'of herself' be bound by a dative DP which does not linearly precede it, paralleling the c-command asymmetries found in the English double object structure (see the translation for each example). ${ }^{3}$ With regard to the animacy constraint, which is also present in the English alternation, the argument interpreted as the goal of motion in (8) can only coappear with the clitic when this argument can be interpreted as the (intended) possessor of the direct object.

${ }^{3}$ Note that the reverse c-command relation is also available for the clitic doubled construction:

(i) Juan le envió cada coto $_{i}$ a $\mathrm{su}_{i}$ propietario.

Juan CL.DAT sent each picture to its owner

As noted in Demonte (1995) and Cuervo (2003), this is expected as the relevant c-command relations hold at the surface level. Thanks to an anonymous reviewer for pointing this out to me. 


\subsection{The applicative analysis of Spanish datives}

Cuervo (2003) builds on the findings by Demonte (1995) and proposes the analysis in (9a) for the prepositional structures in (4), where the VP contains a small clause headed by the relevant preposition. In contrast, the clitic structure in (9b) contains a Low Applicative head (LAppl) à la Pylkkänen (2002).

(9) a. [VP enseñó [PP una retrato de sí ${ }_{i}$ misma [ $\mathrm{P}^{\prime}$ a cada ${ }_{i}$ actriz]]] showed a portrait of herself to each actress

b. [VP enseñó [LApplP a cada $i$ actriz showed each actress.DAT

[LAppl' [LAppl le] una retrato de sí $i_{i}$ misma]]]

CL.DAT a portrait of herself

Note that Cuervo's analysis, as represented in (9), predicts the c-command relations that hold between the accusative and the dative arguments, provided that in her analysis the DO-IO linear order in (9b) results from DO-movement to receive case from $v$ in a local relation. The animacy constraint in (8) derives from the possession relation encoded in Low Appl (Pylkkänen 2002).

As for possessive datives (those exemplified in (1d)), Cuervo (2008) proposes a different applicative head, Middle Appl (MAppl), which is situated above the position of Low Appl in causative verb constructions. The author characterises this type of verbs (e.g., romper 'break') as bi-eventive: they are composed of a causative subevent instantiated in a dynamic light verbal head $v_{\mathrm{DO}}$ ('John breaks the car') and a resultative subevent residing in a stative light verbal head $v_{\mathrm{BE}}$ ('the car is broken'). In this configuration, the argument of Middle Appl is interpreted as an entity affected by the resultative subevent, as shown in (10) for the sentence in (1b) (Juan le rompió el coche a Pedro 'Juan broke Pedro's car'):

(10) [ ${ }_{\mathrm{vP}}$ Juan $v_{\mathrm{DO}}\left[\mathrm{MApplP}\right.$ a Pedro $\quad\left[\mathrm{MAppl}^{\prime}[\mathrm{MAppl} l \mathrm{le}] \quad\left[v \mathrm{P}\right.\right.$ el coche $\left.\left.\left.\left.\left[v_{\mathrm{BE}} \sqrt{ } \mathrm{romp}-\right]\right]\right]\right]\right]$ Juan Pedro.DAT CL.DAT the car $\sqrt{\text { break }}$

Thus, Cuervo (2008) proposes a different structure for the ditransitive/ beneficiary construction in (9b) and the possessive dative in (10), but the middle applicative configuration is only applicable to bi-eventive verbs of the romper-type. However, mono-eventive predicates such as besar 'kiss' or sujetar 'hold' also admit possessive datives: 
(11) a. Juan le sujetó la bolsa a María. Juan CL.DAT held the bag María.DAT

'Juan held María's bag./Juan held the bag for María.'

b. Juan le besó la mano a María.

Juan CL.DAT kiss the hand María.DAT

'Juan kissed María's hand./Juan kissed María on the hand.'

These examples constitute a challenge for Cuervo's analysis, as there is no room for MApplP in a mono-eventive verbal configuration. In section 3, I will provide an account of possessive datives which does not need to refer to verb types.

\subsection{Datives, passivisation and nominalisation}

In her analysis of dative constructions in Spanish, Pujalte (2009) detects a range of asymmetries which are not covered by Cuervo's $(2003,2008)$ explanation. In particular, Pujalte notes that the structures in (1) give different results when we try to nominalise them, as shown in (12):

(12) a. la entrega del premio a María the delivery of.the prize to María

b. *la preparación del bocadillo a su hija the preparation of.the sandwich to his daughter

c. *la instalación del antivirus al ordenador the installation of.the antivirus to.the computer

d. *la rotura del coche a Pedro the breaking of.the car to Pedro

In effect, the examples in (12) seem to indicate that only the ditransitive construction (1a) can be nominalised. However, if we start from the paradigm in (4) instead of looking at the sentences in (1), we can conclude that all the examples in (4) can be nominalised:

(13) a. la entrega del premio a María the delivery of.the prize to María

b. la preparación del bocadillo para su hija the preparation of.the sandwich for his daughter

c. la instalación del antivirus en el ordenador the installation of.the antivirus on the computer 
d. la rotura del coche de Pedro the breaking of.the car of Pedro

Pujalte also notes that passivisation can only apply to the ditransitive structure in (1a), while it is not available for beneficiary, locative and possessive datives:

(14) a. El premio le fue entregado a María.

the prize CL.DAT was delivered María.DAT

'Mary was awarded the prize.'

b. ${ }^{*}$ Los libros le fueron destruidos a la biblioteca.

the books CL.DAT were destroyed library.DAT

'The library's books were destroyed.'

c. * Los estantes le fueron colocados a la habitación.

the shelves CL.DAT were placed room.DAT

'The room was fitted with shelves.'

d. ${ }^{*}$ El coche le fue roto a Pedro.

the car CL.DAT was broken Pedro.DAT

'Pedro's car was broken.'

However, as discussed in Fernández-Alcalde (2013), this account of facts is not completely accurate, as some beneficiary and locative datives do allow passivisation:

(15) a. Al emperador le fue construido un bello mausoleo. the emperor.DAT CL.DAT was built a beautiful mausoleum 'A beautiful mausoleum was built for the Emperor.'

b. Al ordenador le fue instalado un antivirus. the computer.DAT CL.DAT was installed an antivirus 'An antivirus was installed on the computer.'

c. A cada animal le fue colocado un collar satelital. each animal.DAT CL.DAT was placed a collar satellite 'Each animal was fitted with a satellite collar.'

The reason why examples in $(14 \mathrm{~b}-\mathrm{c})$ are not fully acceptable is not clear to me, but word order (in the presence of a dative argument, passive is more natural when the subject remains post-verbal, see Masullo 1992) ${ }^{4}$ as well as the degree of affectedness may play a crucial role. In addition,

\footnotetext{
${ }^{4}$ Thanks to an anonymous reviewer for pointing this out to me.
} 
Pujalte's examples do not sound totally natural in the active voice either, since interpreting the library and the room as affected possessors of the books and the shelves, respectively, does not seem very plausible:

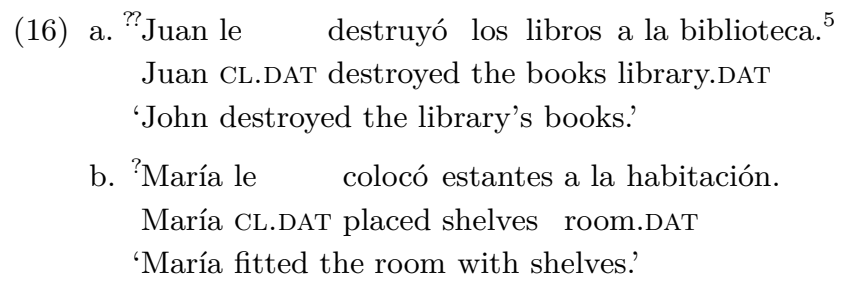

In sum, passivisation only seems to be completely unavailable for possessive datives, as in (14d).

Based on her observations, Pujalte (2009) proposes a distinction between two types of datives: "core datives", which are true internal arguments of canonical ditransitive verbs and can optionally be doubled by the clitic, as in (17a); and "non-core" datives, which are selected for by an applicative head (spelled out as the dative clitic) that adds an additional participant (beneficiary, locative or possessive) to the originally dyadic event, as in (17b).

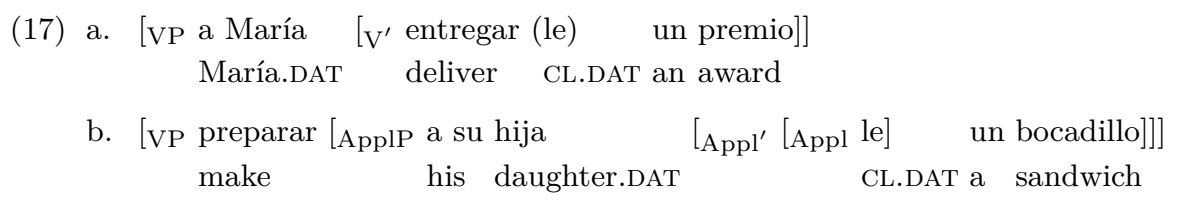

Pujalte bases her analysis on Marantz's (1991) case hierarchy and considers the dative case assigned by Appl as a "dependent" case which only appears when nominative case is assigned and in the presence of a direct object. Given these premises, nominalisations in (12) are ungrammatical due to the absence of nominative case, whereas passives in (14) are bad since the indirect object cannot be case-licensed (see Pujalte 2009 for technical details). Core datives are available both in passives and nominalisations because they bear a "lexical" dative case assigned by V.

Pujalte's (2009) division between core (ditransitive) and non-core (beneficiary, locative and possessive) datives seems to be well founded and supported by clitic doubling and nominalisation facts, but this distinction has also come across some problems. Empirically, the syntactic distinction

\footnotetext{
${ }^{5}$ In fact, it is unclear whether this is a beneficiary dative at all, since possession is
} not altered. See below for details. 
between core and non-core datives is not as clear-cut as Pujalte's analysis predicts, since at least some beneficiary and locative structures can be passivised, whereas the nominalisation data can be observed under a different perspective: only the prepositional structures in (4) can be nominalised, and no "true" datives are allowed in nominal environments.

From a theoretical point of view, Pujalte's analysis of ditransitive structures (her "core datives") as sharing a common underlying structure irrespective of the presence of the clitic (see (17a)) does not provide an explanation for the c-command asymmetries and animacy restrictions that "core" datives show, as exemplified in (7) and (8).

The data so far suggest that datives can be divided in two types: on the one hand, ditransitive, beneficiary and locative structures encode caused possession and can be passivised; on the other, possessive datives are the expression of static possession and cannot undergo passivisation. In the next section, I provide an analysis trying to account for the data presented so far.

\section{Caused possession vs. static possession}

\subsection{The notion of 'caused possession'}

In the previous sections it has become clear that the semantic interpretation of dative structures is a key factor to be taken into account in the explanation of some of the asymmetries they display. Only ditransitive, beneficiary, and locative constructions encode caused (dis)possession in any way, as shown in (18): awarding a prize, preparing a sandwich or installing an antivirus result in María having a prize, Juan's daughter having a sandwich, and the computer having an antivirus. In contrast, breaking a car does not imply that Pedro (no longer) has a car, it just encodes a change of state undergone by the car without altering the possession relation.

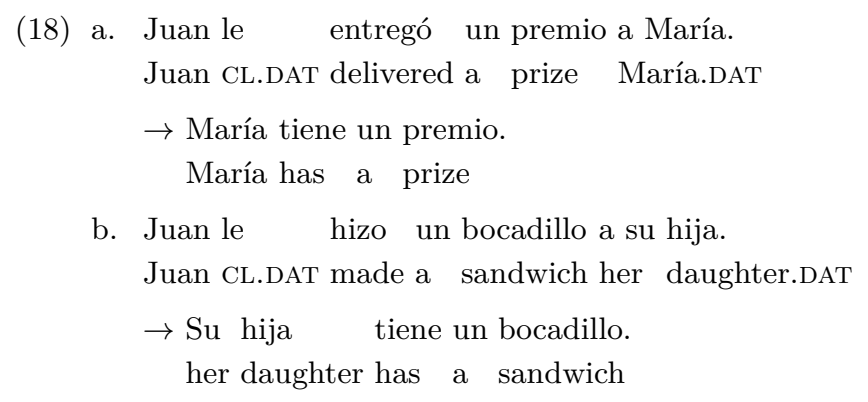


c. Juan le instaló un antivirus al ordenador.

Juan CL.DAT installed an antivirus the computer.DAT

$\rightarrow$ El ordenador tiene un antivirus.

the computer has an antivirus

d. Juan le rompió el coche a Pedro

Juan CL.DAT broke the car Pedro.DAT

$\nrightarrow$ Pedro $\{$ tiene/no tiene $\} \quad$ un coche.

Pedro has/does not have a car

This difference in meaning is not the only factor that plays a role in the asymmetries noted among dative structures. As shown by the nominalisation and passivisation tests, the different types of dative constructions seem to correlate with distinct syntactic structures.

Ditransitive verbs (e.g., entregar 'deliver, award') are essentially triadic verbs which encode a transfer relation between an agent, a theme, and a goal/recipient. This basic meaning can give rise to two different argument structures, precisely those that can appear in the English dative alternation (cf. Pinker 1989, among others): a caused motion structure (19a) and a caused possession structure (19b).

(19) a. SUBJ causes $\mathrm{OBJ}_{1}$ go to $\mathrm{OBJ}_{2}$

b. SUBJ causes $\mathrm{OBJ}_{2}$ have $\mathrm{OBJ}_{1}$

As shown in (20), in the caused motion structure the verb combines with a small clause headed by the preposition $a$ (cf. Pesetsky 1995; Harley 2003):

(20) $\left[{ }_{v \mathrm{P}}\right.$ Juan $v$ [VP entregar [PP un premio [ $\mathrm{P}^{\prime}$ a María]]]]

Juan deliver a prize to María

The caused possession structure, according to Harley's (2003) analysis of English double object constructions, contains a small clause projected by an abstract predicate HAVE, as in (21).

(21) [vP Juan $v$ [VP entregar [haveP María [HAVE un premio]]]]

Juan deliver María a prize

In line with the proposals in Fernández-Alcalde (2013), I consider this alternation between underlying caused motion and caused possession structures as the key syntactic factor that differentiates prepositional (3) and dative (4) constructions, respectively. However, this is not enough to explain the behaviour of possessive datives, as these constructions do not 
denote transfer of possession, but a static possessive relation between both internal arguments. What all dative structures seem to have in common, apart from the obligatory presence of the clitic, is the affected interpretation that is invariably found with dative arguments. The next section is devoted to exploring the connection between the clitic and this affected interpretation.

\subsection{The role of affectedness}

One key property of dative structures is that only affected arguments can appear in this kind of constructions, as exemplified in (22):

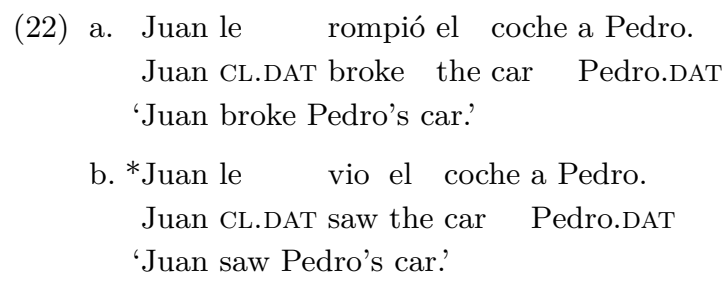

As a proof of affectedness, I will rely on Jackendoff's (1987) "what X did to $\mathrm{Y}$ is $\mathrm{Z}$ " test, where $\mathrm{Z}$ is the action to be tested and $\mathrm{Y}$ is the element that is evaluated for affectedness. In the examples of (22), it is clear that Pedro is affected in (22a), but not in (22b):

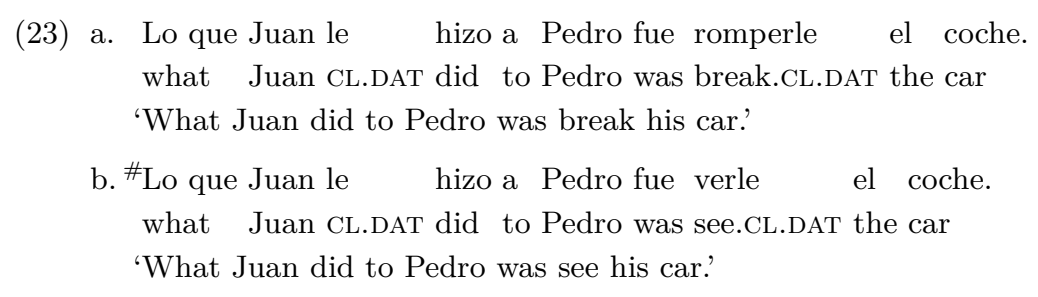

In the light of these facts, Sánchez $(2007,164)$ proposes that "clitics are verbal morphemes or functional heads with uninterpretable features (phifeatures) and interpretable features (affectedness) which are related to the assignment of a structural dative case". In her approach, this functional head is an instance of $\mathrm{V}$ in a complex predicate configuration. Other authors have proposed a similar functional head in this position, see, for example Marantz's (1991) Benefactive phrase, Koizumi's (1993) $\Omega$ Phrase, Brugger \& Poletto's (1993) AgrIO, or Demonte's (1995) Clitic Phrase. On different grounds, Baker and Collins (2006) also argue for a similar $v \mathrm{P}$ 
internal functional projection called Linker Phrase, headed by a [+EPP] head which enables the Case-licensing of all the nominals inside $v \mathrm{P}$, as shown in (24):

(24) $\left[v \mathrm{P} v\left[\mathrm{LkP} \_\mathrm{Lk}^{0}[\mathrm{VP} \mathrm{XP}[\mathrm{V} \mathrm{YP}]]\right]\right]$

In a similar vein, Bleam (1999) proposes an aspectual projection sitting between VP and $v \mathrm{P}$ for Spanish datives. Travis (2010) also argues for a similar functional head, which she identifies with inner aspect, sitting above the lower layer of a split VP, as shown in (25):

(25) $\left[\mathrm{VP}_{1} \mathrm{~V}_{1}\left[\mathrm{AspP} — \mathrm{Asp}^{0}\left[\mathrm{VP}_{2} \mathrm{XP}\left[\mathrm{V}_{2} \mathrm{YP}\right]\right]\right]\right]$

(Travis 2010, 5)

In line with Bleam (1999) and Travis (2010), and building on the analysis presented in Fernández-Alcalde (2013), I assume that this aspectual head, situated on top of VP and below $v \mathrm{P}$, plays a double role: semantically, it is the locus of the affected interpretation found in the dative argument; syntactically, this head is responsible for dative case assignment to the DP via agreement.

\subsection{Caused possession in ditransitive structures}

In this section, I will propose an analysis for ditransitive structures based on Harley's (2003) structure in (21), but including the head Asp between $v \mathrm{P}$ and VP. In this configuration, Asp functions as a Probe (cf. Chomsky 2001) and establishes an agreement relation with the DP subject of HAVE. This operation checks the uninterpretable phi-features of Asp with the matching interpretable features of DP. As a result, the DP receives dative case and shows number agreement with the clitic. Assuming Asp contains an EPP-feature, this DP moves to Spec-Asp to satisfy this requirement.

Similarly, the next functional head $(v)$ also acts as a Probe for agreement and checks its uninterpretable phi-features against the interpretable phi-features of the complement of HAVE, which receives accusative case. As $v$ is also provided with an EPP feature, the complement of HAVE (the surface direct object) moves to Spec- $v$, and thus the unmarked order, where the direct object precedes the indirect object, is obtained (cf. Cuervo 2003). This set of operations is represented in (26) for the sentence Juan le entregó una foto de sí misma a cada alumna 'Juan handed each student a photo of herself'. 
(26)

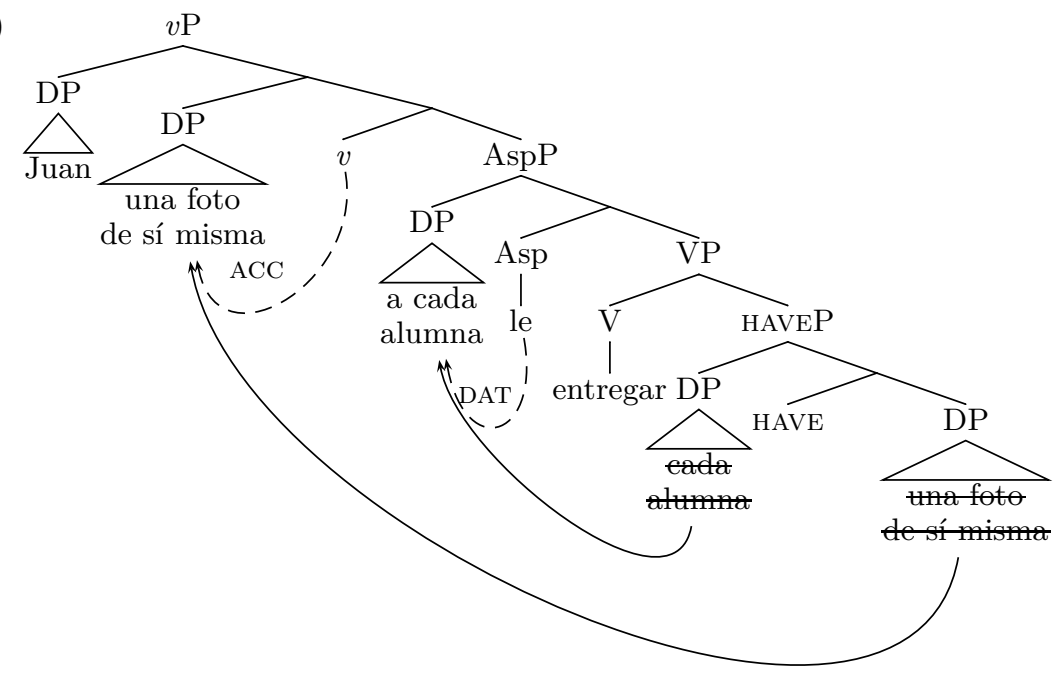

Note that $v$ cannot target the DP cada alumna to check its EPP features: once Asp has established agreement with the DP cada alumna and checked dative case against it, the DP becomes frozen in place, in the sense of Chomsky (2001). In addition, if $v$ targeted the DP cada alumna to check EPP, the lower DP una foto de sí misma would remain caseless, causing the derivation to crash.

As a first consequence of this analysis, where different structures for clitic-doubled (26) and non-doubled (20) structures are assumed for ditransitives, the c-command asymmetries in (7) and the animacy/possession restriction in (8) receive a straightforward account. With regard to the binding data in (7), (26) is the only configuration where the indirect object ever c-commands, and thus can bind, an anaphora contained in the direct object. In (20), the direct object is not c-commanded by the indirect object at any stage of the derivation, and thus the anaphor in the direct object is not licensed.

The animacy/possession restriction in (8) follows directly from the presence of the predicate HAVE in (26), but not in (20). This predicate imposes the same semantic restrictions on its subject as the actual verb have, so it must be interpreted as a possessor, whereas the head Asp imposes an affected interpretation on the DP with which it agrees. Thus, the ungrammaticality of (8a) follows from the fact that the DP Madrid cannot satisfy these interpretive requirements (affected possessor), whereas it can perfectly well be interpreted as a mere goal of motion in (20). 


\subsection{Caused possession in locative structures}

Locative verbs (e.g., instalar 'install') select primarily for a prepositional small clause identical to the prepositional structure in ditransitives (20), as the prepositional complement of these verbs is interpreted as a goal of motion:

(27) [ $v \mathrm{P}$ Juan $v$ [VP instalar [PP un antivirus [ $\mathrm{P}^{\prime}$ en el ordenador]]]] Juan installed an antivirus on the computer

However, locative verbs can also combine with a possessive structure provided that the goal of motion can also be interpreted as an affected possessor of the theme. As above, the head Asp that merges between VP and $v \mathrm{P}$ agrees with the subject of HAVE, as shown in (28) for Juan le instaló un antivirus al ordenador 'Juan installed an antivirus on the computer'.

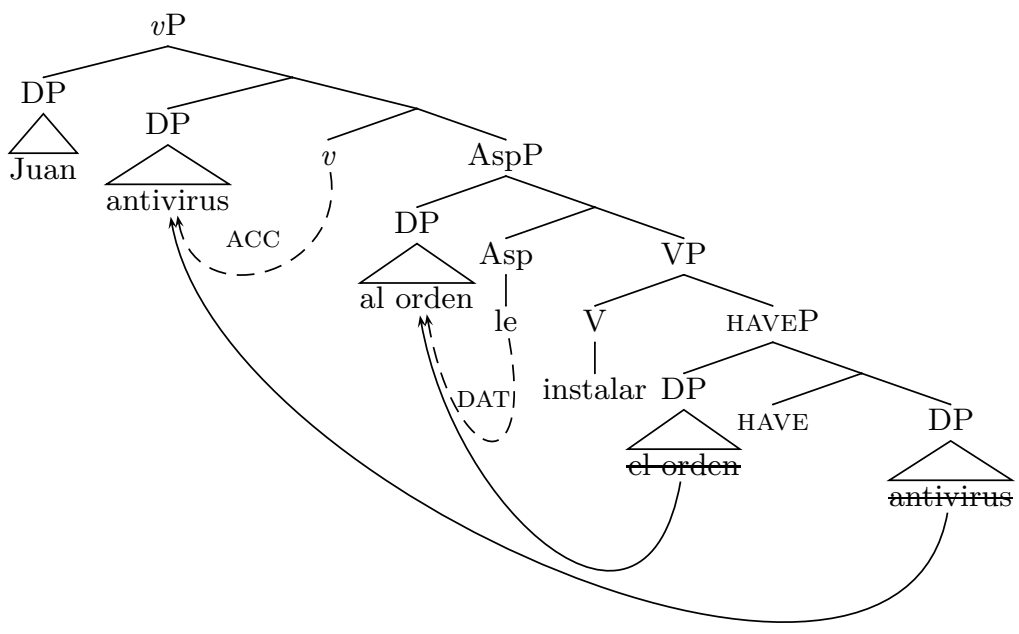

That means locative and transfer verbs behave very similarly with regard to datives. They both can show up as caused motion and caused possession structures. The reason why they are usually seen as different verb classes is that ditransitive verbs are more heavily associated with the meaning of 'transfer'. However, as seen in example (8b), ditransitive verbs such as enviar 'send' are also found not to work well with datives when the possession requirement is not met. 


\subsection{Benefactive constructions and caused possession}

Benefactive constructions are usually headed by predicates of creation that basically codify a dyadic relation, although they can also take an optional adjunct denoting the beneficiary of the event, which is introduced by the preposition para 'for', as in (29):

(29)

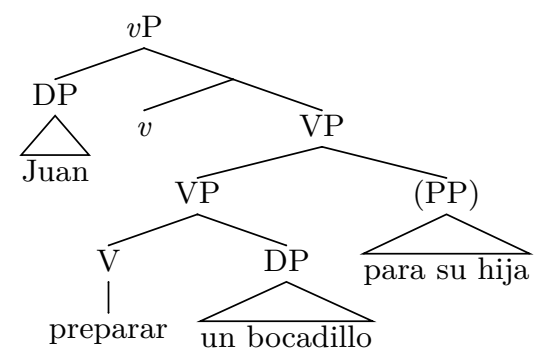

The test of the proform hacerlo 'do so' (cf. Culicover 1997; Stroik 2001; Saab 2010, among others) confirms the non-argumental nature of this PP, as opposed to the argument status of the PP which appears with ditransitive or locative verbs. This proform can replace the whole $v / \mathrm{VP}$ leaving adjuncts, but not arguments, behind. As shown in (30a), the ditransitive PP cannot be expressed in the presence of this proform since it is an argument. Conversely, the PP headed by para is compatible with hacerlo, as shown in (30b), which is what we expect if it is indeed an adjunct:

(30) a. *Juan entregó un libro a María y Pedro lo hizo a Laura. Juan delivered a book to María and Pedro did so to Laura

b. Juan construyó una casa para María y Pedro lo hizo para Laura. Juan built a house for María and Pedro did so for Laura

But these verbs also allow for the possibility of combining with a possessive structure, so that the creation event is construed as the cause of the possession event. This combination is instantiated in the same way as in ditransitive and locative verbs, i.e., with a HAVEP as the complement of $\mathrm{V}$ and an AspP merged between $\mathrm{VP}$ and $v \mathrm{P}$ and encoding the affected interpretation (31).

In contrast with the structure in (29), (31) captures the fact that the beneficiary DP (su hija 'his daughter') is interpreted both as the possessor of the theme argument (un bocadillo 'a sandwich') and as an affected argument. In fact, the do so test confirms that the doubled dative DP is part of the argument structure (see (32)). 
$(31)$

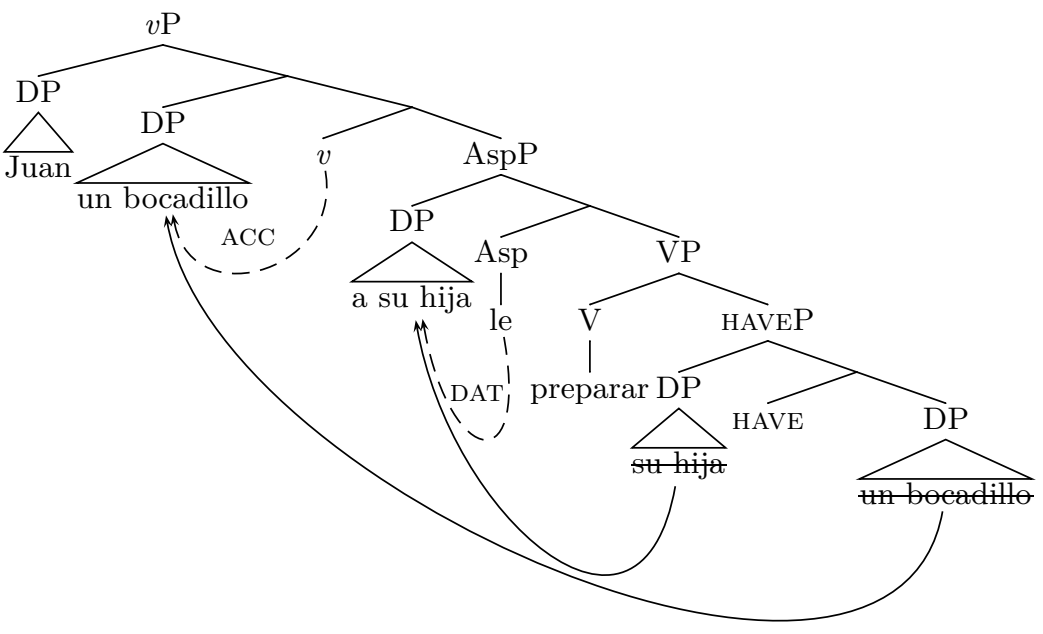

$(32) *$ Juan le $\quad$ preparó un bocadillo a su hija

y Pedro lo hizo a su hermana Juan CL.DAT made a sandwich her daughter.DAT and Pedro did so his sister.DAT

In addition, the dative structure passes the affectedness test, while the prepositional phrase does not show any affected interpretation, as expected:

(33) a. Lo que Juan le hizo a su hija fue prepararle un bocadillo. what Juan CL.DAT did to his daughter.DAT was make.CL.DAT a sandwich

b. ${ }^{\#}$ Lo que Juan hizo para su hija fue preparar un bocadillo. what Juan did for his daughter was make a sandwich

\subsection{Possessive datives and static possession}

In the case of static possession constructions, the possessor DP is not an argument of the event, but a part of a bigger DP which also contains the possessum. The surface dative merges as the specifier of this DP and later undergoes possessor raising (cf. Landau 1999) triggered by Asp and followed by DP-remnant movement to the specifier of $v \mathrm{P}^{6}$ As a result, the

${ }^{6}$ See É. Kiss (2014) for a detailed discussion on external possessors and for the possibility that external possessors are based generated outside the maximal projection containing the possessum, and are introduced as affected participants coindexed with the pro possessor of a coargument. This option is fully compatible with the data presented here, as nothing in the analysis crucially depends on actual movement. 
possessor receives dative case from Asp and is interpreted as an affected argument.

$(34)$

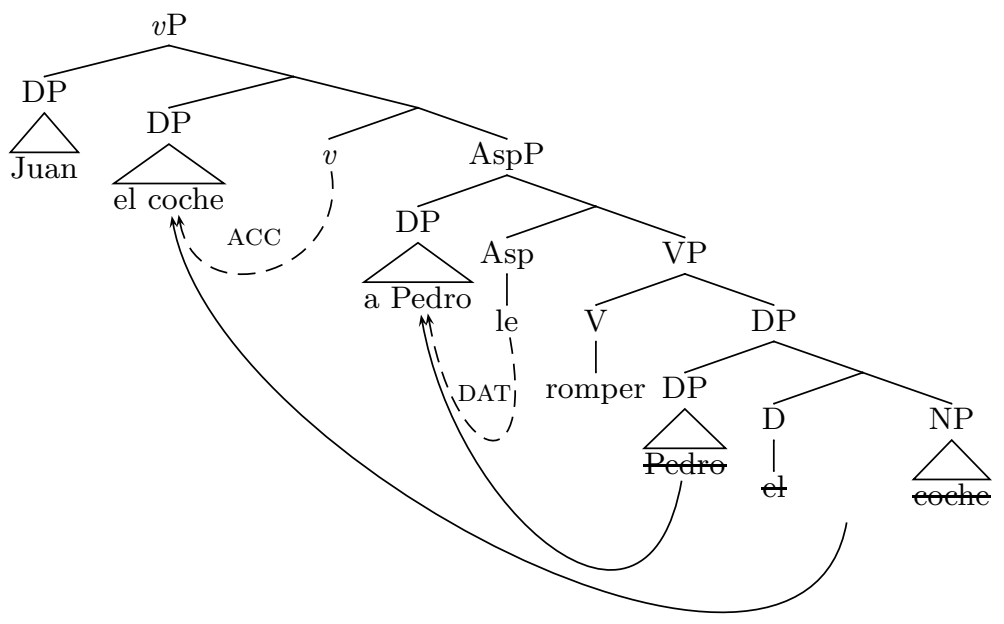

The prepositional construction which corresponds to the dative structure derives from the usual way of expressing possessors in Spanish, i.e., a PP headed by the preposition de as a complement of the possessum:

(35) $[v \mathrm{P}$ Juan $v[\mathrm{VP}$ romper [DP el coche [PP de Pedro]]]]]

$$
\text { Juan break the car of Pedro }
$$

Both in (34) and (35) the possessor and the possessum are generated within the only DP selected for by the verb. This analysis is consistent with the fact that these structures convey a static possession meaning, with no transfer of possession involved. As in other possessor-raising approaches, this proposal raises the question whether the complement DP in (34) and (35) can be transformationally related, but the answer to this question does not seem to affect the main predictions of the analysis presented here.

\subsection{Nominalisation and passivisation in dative structures}

The current analysis of dative second objects provides a straightforward account of the nominalisation and passivisation data noted by Pujalte (2009) and exemplified in (12) and (14).

As advanced in section 2.3, the explanation for the apparent contrast in (12) lies in the distinction between dative (3) and prepositional (4) structures, which is sometimes overlooked due to the phonological identity 
of the dative marker and the preposition $a$. The two internal arguments of a root in a verbal environment can be spelled out as a DP and a PP, or as two DPs, one of them in dative case. Both options are possible when the root is spelled out as a verb, as the first argument is assigned accusative case and the second one is either a PP or receives dative case from Asp. However, when the root is spelled out as a noun, only the first possibility arises: the first argument is marked with genitive case and the second one is licensed as a PP. The scenario where the noun combines with two DP arguments is not available, since dative case cannot be assigned within the DP. In sum, none of the structures in (3) can be nominalised, only those in (4) can. ${ }^{7}$

Upon closer inspection, the passivisation asymmetries observed by Pujalte (2009) turned out to be less pronounced than what she suggests (cf. (14) and (15)). In fact, the only dative structure out of the ones listed in (3) that cannot be passivised is the possessive dative. This is due to the fact that possessive datives have a different structure than ditransitive, beneficiary and locative constructions (compare the trees in (26), (28), and (31) with the one in (34), where the dative DP is not an argument of the event, but a part of one of its arguments). I assume, following Gehrke \& Grillo (2009), that passive is a syntactic operation which relies on event structure, and thus can act upon an argument of the event, but not upon a subpart of an argument. In fact, the prepositional construction that paraphrases the possessive dative structure can undergo passivisation, since the DP is targeted as a whole (36a). However, when only a part of the DP is extracted, as in (36b), the prepositional alternant shows the same ungrammaticality effects as the dative structure (repeated in (37) for the sake of clarity):

(36) a. [El coche de Pedro] fue roto _ por Juan.

the car of Pedro was broken by Juan

'Pedro's car was broken by Juan.'

b. *EL COCHE fue roto [__ de Pedro] (no la bici).

the car was broken of Pedro not the bike

'It was Pedro's car (not his bike) which was broken.'

${ }^{7}$ One anonymous reviewer notes that datives are allowed in some nominal structures, as in ataque a los soldados lit. 'attack to the soldiers', acoso a las tropas lit. 'harrasment to the troops'. However, it is not without controversy that these $a$-phrases can be considered datives, as they bear accusative case in the verbal construction: atacaron a los soldados $\sim$ los atacaron 'they attacked the soldiers $\sim$ they attacked them.ACC'. This phenomenon is extensively discussed in FernándezAlcalde (2012), where arguments are presented that these are indeed prepositional phrases. 
$(37) * \mathrm{El}$ coche le fue roto $[\ldots$ a Pedro $]$.
the car CL.DAT was broken

In contrast, both possibilities of extraction are available in active constructions, as shown in (38):

(38) a. EL COCHE le rompieron a Pedro (no la bici). the car CL.DAT broke.3PL to Pedro not the bike 'It was Pedro's car (not his bike) that they broke.'

b. EL COCHE encontraron de Pedro (no la bici). the car found.3PL of Pedro not the bike 'It was Pedro's car (not his bike) that they found.'

As these tests show, passivisation of possessive dative structures is not possible as a result of the application of possessor raising. However, the exact nature of this incompatibility is still not completely clear, and I would like to leave this issue open for further research.

\section{Conclusions}

In this paper, I have discussed Spanish constructions that contain a dative argument that is traditionally referred to as an indirect object. Even though superficially all of these dative arguments seem to be second objects of the verb preceded by the same marker $(a)$, showing what looks like optional clitic doubling, they do not form one homogeneous class. Clitic doubling is in fact absent if the third argument is a PP headed by an appropriate preposition. This preposition can be the preposition $a$, which is phonologically non-distinct from the dative case marker $a$. Clitic doubling is obligatory if the construction involves two internal arguments, one of which is a dative-marked DP.

Building on previous work (Fernández-Alcalde 2013), I have presented evidence that structural and semantic asymmetries exist between different types of Spanish clitic-doubling dative constructions. From the semantic point of view, a clear distinction needs to be made between dative structures encoding caused possession and those denoting static possession. Caused possession is found in ditransitive (e.g., entregar 'deliver'), beneficiary (e.g., preparar 'make, prepare') and locative (e.g., instalar 'install') verbs, whereas static possession arises with various classes of verbs, as this structure does not impose special requirements on the context it can appear in. 
These semantic differences have direct consequences on the syntax. The structures which codify caused possession include a possessive predicate which is interpreted as a resultative component of the event. In contrast, static possession is encoded within the only complement DP of the verb. In both cases, the possessor is syntactically licensed by an aspectual head merged between VP and $v \mathrm{P}$, which is spelled out as the clitic. This functional head, associated with the semantics of affectedness, probes for and agrees with the possessor, which receives dative case and shows an affected interpretation.

\section{References}

Baker, Mark C. and Chris Collins. 2006. Linkers and the internal structure of $v \mathrm{P}$. Natural Language and Linguistic Theory 242. 307-354.

Bally, Charles. 1926. L'expression des idées de sphère personnelle et de solidarité dans les langues Indo-européennes. In F. Fankhauser and J. Jud (eds.) Festschrift Louis Gauchat. Aarau: Verlag H. R. Sauerländer. 68-78.

Barss, Andrew and Howard Lasnik. 1986. A note on anaphora and double objects. Linguistic Inquiry 17. 347-354.

Bleam, Tonia. 1999. Leísta Spanish and the syntax of clitic doubling. Doctoral dissertation. University of Delaware.

Brugger, Gerhard and Cecilia Poletto. 1993. On negation in German and Bavarian. University of Venice Working Papers in Linguistics 3. 41-80.

Chomsky, Noam. 2001. Derivation by phase. In M. Kenstowicz (ed.) Ken Hale: A life in language. Cambridge MA: MIT Press. 1-52.

Cuervo, María Cristina. 2003. Datives at large. Doctoral dissertation. MIT.

Cuervo, María Cristina. 2008. La alternancia causativa y su interacción con argumentos dativos. Revista de lingüística teórica y aplicada 46. 55-79.

Cuervo, María Cristina. 2010. Against ditransitivity. Probus 22. 151-180.

Culicover, Peter. 1997. Principles and parameters. Oxford: Oxford University Press.

Demonte, Violeta. 1995. Dative alternation in Spanish. Probus 7. 5-30.

É. Kiss, Katalin. 2014. Ways of licensing external possessors. Acta Linguistica Hungarica 61. $45-68$.

Fernández-Alcalde, Héctor. 2012. Preposiciones y caso en la estructura de los verbos del español. Interlingüística 22. 349-362.

Fernández-Alcalde, Héctor. 2013. Datives, prepositions, and argument structure in Spanish. In S. Baauw, F. Drijkoningen, L. Meroni and M. Pinto (eds.) Romance languages and linguistic theory 2011. Selected papers from "Going Romance" Utrecht 2011. Amsterdam \& Philadelphia: John Benjamins. 125-142.

Fernández-Soriano, Olga. 1999a. Datives in constructions with unaccusative se. Catalan Working Papers in Linguistics 7. 89-105.

Fernández-Soriano, Olga. 1999b. Two types of impersonal constructions in Spanish: Locative and dative subjects. Syntax 2. 101-140. 
Gehrke, Berit and Nino Grillo. 2009. How to become passive. In K. Grohmann (ed.) Explorations of phase theory: Features, arguments, and interpretation at the interfaces. Berlin \& New York: Mouton de Gruyter. 231-268.

Green, Georgia M. 1974. Semantics and syntactic regularity. Bloomington, IN: Indiana University Press.

Harley, Heidi B. 2003. Possession and the double object construction. Linguistic Variation Yearbook 2. 29-68.

Jackendoff, Ray. 1987. The status of thematic relations in linguistic theory. Linguistic Inquiry 18. 369-411.

Koizumi, Masatoshi. 1993. Object agreement phrases and the split VP hypothesis. MIT Working Papers in Linguistics 18. 99-148.

Lamiroy, Béatrice and Nicole Delbecque. 1998. The possessive dative in Romance and Germanic languages. In W. V. Langendonck and W. V. Belle (eds.) The dative. Volume 2: Theoretical and contrastive studies. Amsterdam \& Philadelphia: John Benjamins. 29-74.

Landau, Idan. 1999. Possessor raising and the structure of VP. Lingua 107. 1-37.

Marantz, Alec. 1991. Case and licensing. In G. F. Westphal, B. Ao and H.-R. Chae (eds.) ESCOL '91: Proceedings of the Eighth Eastern States Conference on Linguistics. Columbus, OH: Ohio State University. 234-253.

Masullo, Pascual J. 1992. Incorporation and case theory in Spanish: A crosslinguistic perspective. Doctoral dissertation. University of Washington.

Oehrle, Richard Thomas. 1976. The grammatical status of the English dative alternation. Doctoral dissertation. Massachusetts Institute of Technology.

Pesetsky, David. 1995. Zero syntax: Experiencers and cascades. Cambridge MA: MIT Press.

Pinker, Steven. 1989. Learnibility and cognition: The acquisition of argument structure. Cambridge MA: MIT Press.

Pujalte, Mercedes. 2009. Condiciones sobre la introducción de argumentos: el caso de la alternancia dativa en español. MA thesis. Universidad Nacional del Comahue.

Pylkkänen, Liina. 2002. Introducing arguments. Doctoral dissertation. Massachusetts Institute of Technology.

Saab, Andrés. 2010. Silent interactions: Spanish TP-ellipsis and the theory of island repair. Probus 22. $73-116$.

Sánchez, Cristina. 2007. The possessive dative and the syntax of affected arguments. In I. Gil, H. Fernández-Alcalde and R. González (eds.) Cuadernos de Lingüística del I. U. I. Ortega y Gasset 14. Madrid: I. U. I. Ortega y Gasset. 153-173.

Stroik, Thomas. 2001. On the light verb hypothesis. Linguistic Inquiry 32. 362-369.

Torrego, Esther. 1998. The dependencies of objects. Cambridge MA: MIT Press.

Travis, Lisa. 2010. Inner aspect. Dordrecht: Springer. 